\title{
RURAL DEVELOPMENT IN \\ BANGLADESH: AN ASSESSMENT OF \\ TRAINING, RESEARCH AND \\ ACTION RESEARCH OF \\ BANGLADESH ACADEMY FOR \\ RURAL DEVELOPMENT (BARD)
}

\author{
Jannatul FERDOUS 1 \\ DOI: 10.35782/JCPP.2020.4.02
}

\begin{abstract}
Bangladesh is a vast area of rural states. Rural development endeavors for the progress of the value of life in the rural extents with synchronized determinations to expedite the growth, efficiency, and welfare of the populations. Bangladesh is not a beginner in the arena of rural development; somewhat it inbred long years of practices in this arena. Nowadays, rural extents are facing key challenges that arise largely from globalization. The forceful progression of globalization involved in the market economy has been insistently shifting the old thoughts, practices and methods of rural development, predominantly in the developing states like Bangladesh. The Bangladesh Academy for Rural Development (BARD) is a fifty-five years old organization functioning for the rural development sector. A small team of faculty members started the expedition of intense new tracks for development designers and rural development managers with the energetic direction of the first Director Dr. Akhter Hameed Khan. All through the years the academy retained strong effects on rural development. Here, an attempt has been made to measure the performance of $B A R D$ in the age of globalization on the ground of Training, Research and Action Research criteria.
\end{abstract}

Keywords: performance, $B A R D$, training, research, action research

\section{Introduction}

Globalization is a course of intensifying trade and business, making commercial boundaries less meaningful around the world (Jora, 2006). The importance of globalization varies for persons, crowds and states. The influence of different worldwide drifts differs on the phase of financial growth of a state, its capital flows, its

1 Assistant Professor. Department of Public Administration, Comilla University, Cumilla-3506, Bangladesh. E-Mail: jannat.lata@yahoo.com 
contact to technology, its democratic organizations, or cultural features (Pop et al., 2013). In supplementary arguments, the core of the issue is the "Difference Entrance" to influence, where influence is abstracted as the capability to transfigure physical conditions - whether financial, governmental or societal and to attain objectives grounded on the utilization of wealth, the formation of the rule structure, and the mechanism of setups and establishments. The disparity, the uneven and irregular entrance to the principal organizations, associations and procedures of the new inclusive order have, thus, come under swelling attack (Hussain, 2011). Nowadays, the advanced and developing states are more or less inside the crease of globalization. With its increasing influence of exports and imports, Bangladesh is no exemption to that. Globalization is increasingly prevalent, as many states see their affluence in this process (Jalil, 2011). Followers of globalization assert that the procedure offers prospects for deprived people in developing states to progress their livings and to develop out of poverty, while agnostics state that globalization postures new threats to the welfare of poor societies (von Braun \& Mengistu, 2009).

Bangladesh has a population of 161 million, approximately $75 \%$ of whom are living in rural extents (Kibria, 2015). Given this high proportion, rural expansion is a vibrant matter for the process of social inclusion. Rural development denotes progress in the welfare of the societies living in the rustic zone (Hossain, 2004; Ignat et al., 2014). Globalization encompasses multilateralism and manifold methods. It is unavoidable in today's atmosphere; there is a crucial necessity to address the socioeconomic aspects that arise as a concern of a universal market economy. Globalization necessitates a procedure of reworking and rearrangement of rural development (Hasan, 2000). BARD is a state organization designated to encourage rural development by research, training and action research. BARD is known both nationally and internationally for its groundbreaking role in emerging, pioneering and sharing tactics in rural development (Jashimuddin et. al, 2005). This paper attempts to measure the performance of BARD on the ground of Training, Research and Action Research criteria.

\section{Objectives of the Study}

The objectives of the study are to:

1. Examine the present status of the performance of BARD in research, training and action research;

2. Assess the challenges in the performance of BARD in research, training and action research;

3. Propose some recommendations to overcome the difficulties facing by BARD in research, training and action research.

\section{Methodology}

The prevailing study is on the performance of the BARD with special focus on training, research and action research. Performance can be understood as a progress over a period of time. In this situation, the case study method is employed for the purpose of 
the paper. Primary data has also been collected directly from the region of the study. The study had utilized two apparatuses for collecting primary data, namely direct observation and interviews. An interview through a uniform questionnaire was steered to collect both quantitative and qualitative information from BARD. The interview was carried out from the first week of August 2016 to middle of September 2016. Thus, the primary outcomes of the comprehensive interviews were carried out to understand the performance of "BARD" on the basis of the interview guide. Purposive sampling is a process where definite units are decisively selected from the choice of the researchers (Aminuzzaman, 2011). There are 60 faculty members in BARD, however, only 39 are attending BARD prevalently. Thus, the size of the sample was chosen at nearly half of the prevailing attendees, hence 20. Table 1 details the number of respondents and their ranks in BARD. Secondary data has been obtained from published documents, such as journals, books, annual reports, research reports and internet browsing.

Table 1: Number of Respondents and Ranks

\begin{tabular}{|l|c|}
\hline \multicolumn{1}{|c|}{ Rank } & Number \\
\hline Director & 3 \\
\hline Joint Director & 7 \\
\hline Deputy Director & 6 \\
\hline Assistant Director & 4 \\
\hline \multicolumn{1}{|c|}{ Total } & 20 \\
\hline
\end{tabular}

Source: author's own representation

\section{Conceptual Clarification}

\section{Performance}

Performance is frequently defined in output relations, as the attainment of certain given aims (Garcia, 2017). However, performance is not only an issue of what individuals attain, but also of how they attain it (Armstrong, 2006). Performance can thus be approached in two ways. The first is evaluative and denotes the activities that can be referred as adverse, impartial, or constructive for individual and administrative efficiency. The second is multidimensional and denotes that there are many diverse types of activities that have the capability to develop (or obstruct) administrative objectives (Aguinis, 2011). When dealing with performance, both efforts (actions) and productivities (outcomes) need to be measured.

\section{Performance Management}

Performance management is a deliberate procedure whose key components are arrangement, dimension, feedback, constructive support and negotiation. It is apprehensive with assessing outcomes in the form of providing performance associated with potentials articulated as goals (Armstrong, 2006). 


\section{Globalization}

Globalization denotes a progressively assimilated global economy with fewer trade blocks, unobstructed capital movement, cost-effective labor and unrestrictive economy, which infers fewer government involvement (Meraj, 2013). Globalization is mostly based on economic practices concerning trade relationships and market procedures. It is a multifaceted procedure, the nature of which is not entirely assumed. Globalization can have various meanings, providing diverse consequences to diverse states and diverse clusters of people. The exponents, in their opinions for globalization, commonly exclude several of the most vital matters about the welfare of populations, for instance human rights, the liability of military expenditure, dishonesty and traditional distinctiveness, which fall into the cultural and political grounds. The antagonists are apprehensive about undesirable, unanticipated influences of financial globalization, and sense it should be clogged or significantly reformed (Lim, 2005).

\section{Background of BARD}

The Academy for Rural Development has been established on the 27th of May 1959 in Comilla (BARD, 1973). BARD began its journey under the active management of Dr. Akhter Hameed Khan, its first Director, small group of faculty members and rural development managers (BARD, 1986). The actual name of Dr. Akhter Hameed Khan arouses a multitude of qualities that are appropriate to a man of his worth. He was a versatile and unusual mastermind, a man of unparalleled devotion and promise, a high personality, a great idealistic humanist with profound affection and kindness for the poor, a commited social scientist, and a master of generating innovation (Bhattacharjee, 2009). BARD is a prominent organization in Bangladesh, involved in training, research and action-research in rural development. Its intents and tasks contain conduct of research and action-research for devising rural development strategies and packages, and training of employees from different government and non-government groups interested in rural development. The Academy has developed numerous groundbreaking rural development programmes and organizations throughout the entire country. BARD has helped policy makers with facts and understanding about the complications of rural development in Bangladesh through its incorporated method of research, training and action-research (Ahmed \& Quddus, 1993). BARD established an enduring affiliation with rural people in Bangladesh at large and with those in the Comilla Sadar administrative district in particular. Inhabitants have instinctively and enthusiastically contributed in several experimentations take on by the Academy and thus detonated the mythos about the outmoded traditionalism of the peasantry. The researchers and the Academy, instructors and field workers owe their achievement to these people. They still persist and will stay to continue the significant basis of motivation for the Faculty members of the Academy (BARD, 1991). In the existent days as well, BARD has a vital role to play in the advancement procedure of the state.

BARD is run by a Board of Governors of which the Minister for Local Government, Rural Development and Cooperatives is the Chair. Organizationally, it is involved in the Ministry of Local Government, Rural Development and Cooperatives (Islam et al., 2015). The Board of Governors articulates the policies, and the Director General offers 
the power for executing the policies of BARD, as he is the principal executive and is steering the day to day matters, within the context of the Act and the Rules of Service the Academy. He is supported by an Additional Director General. The functions of the Academy are accomplished by its Faculty which includes nine Divisions, each one headed by a Director. The divisions are separated into two sets: Service Divisions and Academic Divisions. The Service Divisions includes Research, Training, Projects and Administration. The Academic Divisions include Rural Sociology, Rural Economics, Rural Administration, Agricultural Development and Rural Education. Yet again, the five Academic Divisions contain several disciplines: Rural Administration, Rural Economics and Rural Business Management, Rural Sociology, Demography and Development Communication, Agricultural Extension and Agricultural Technology, Rural Education and Community Health \& Nutrition. There are 60 Faculty members: one Director General, one Additional Director General, nine Directors, 14 Joint Directors, 13 Deputy Directors and 22 Assistant Directors. They are assisted by 305 supportive staff and officials (BARD, n. d.). The Academy has appeared as an organization of an exclusive form uniting training with research and pilot investigation in the arena of rural development. It has been involved in numerous kinds of pilot investigation to discover replicable models of Agriculture, Rural Administration, Cooperatives, Community Health and Nutrition, Women and Youth Works.

\section{Performance of BARD in the Age of Globalization}

Rural development is considered as one of the vital policies for development of any state and Bangladesh is not excluded from this issue. In Bangladesh, rural development is profoundly rooted in the BARD. Since the early 1960's, BARD has presented many pioneering resolutions to rural difficulties, helping Bangladesh make significant advancements in rural development (Islam et al., 2015). Offering training, leading research and experimenting innovations are the compulsory tasks of BARD, which has advanced some exclusive models of development administration (Kabir et al., 2004).

\section{Training}

The academy is a branded as a national training institute. Its training clientele comprises both of officials and non-officials. Officials involve civil servants, officers of nation building sectors and international candidates of development organizations, whereas the non-officials include the local leaders, councilors and affiliates of co-operatives, learners of educational organizations and associates of voluntary groups. Moreover, a huge figure of imitational clients including scholars, consultants, students, government officials, affiliates of diplomatic corps and imitational organizations visit the academy (Ahsan et. al., 2012).

BARD remains to appeal for trainees from diverse government organizations, local level groups and non-government organizations (NGOs) along with trainees, viewers and guests from overseas. BARD has added huge experience in the arena of training, offering about 120 training courses per year. Moreover, BARD has developed 30 training units under the comprehensive set of rural development. Different courses are 
presented on request with a rational budget. For organizing training courses, requests are made to the Director General or Director (Training).

All of the respondents revealed that the target of training can be achieved through the existing setting. The setup of BARD is worthy for organizing training courses. Only $20 \%$ of the respondents revealed that the quality of training was not good enough good. They have recommended focusing on the quality of trainings instead of the quantity. Tables 2-4 indicate the performance of the training events of BARD between 2012 and 2015. Against a target of 110 courses, the academy arranged a total of 85 courses, with 3905 participants, compared to the target of 3763 throughout the period of 2012-13.

Table 2: Achievement of Courses, Participants and Man days against Target in the Year 2012-13

\begin{tabular}{|c|l|c|c|c|c|c|c|}
\hline \multirow{2}{*}{$\begin{array}{c}\text { S1. } \\
\text { No. }\end{array}$} & Nature of Course & \multicolumn{3}{|c|}{ Target } & \multicolumn{3}{c|}{ Achievement } \\
\cline { 3 - 8 } & $\begin{array}{c}\text { Course } \\
\text { (No.) }\end{array}$ & $\begin{array}{c}\text { Partici- } \\
\text { pants } \\
\text { (No.) }\end{array}$ & $\begin{array}{c}\text { Man } \\
\text { days }\end{array}$ & $\begin{array}{c}\text { Course } \\
\text { (No.) }\end{array}$ & $\begin{array}{c}\text { Partici- } \\
\text { pants } \\
\text { (No.) }\end{array}$ & $\begin{array}{c}\text { Man } \\
\text { days }\end{array}$ \\
\hline A. & $\begin{array}{l}\text { International Training/ } \\
\text { Workshop/ Seminar/ } \\
\text { Conference/ Orientation } \\
\text { Programme }\end{array}$ & 11 & 95 & 990 & 04 & 55 & 231 \\
\hline B. & $\begin{array}{l}\text { National Training Course/ } \\
\text { Professional Training Course }\end{array}$ & 99 & 3668 & 36152 & 81 & 3850 & 3794 \\
\hline & \multicolumn{1}{|c|}{ Total } & 110 & 3763 & 37142 & 85 & 3905 & 4025 \\
\hline
\end{tabular}

Source: Ashan et al., 2013

Table 3: Achievement of Courses, Participants and Man days against Target in the Year 2013-14

\begin{tabular}{|c|l|c|c|c|c|c|c|}
\hline Sl. & \multicolumn{1}{|c|}{ Nature of Course } & \multicolumn{3}{|c|}{ Target } & \multicolumn{3}{c|}{ Achievement } \\
\cline { 3 - 8 } & & $\begin{array}{c}\text { Course } \\
\text { (No.) }\end{array}$ & $\begin{array}{c}\text { Partici- } \\
\text { pants } \\
\text { (No.) }\end{array}$ & $\begin{array}{c}\text { Man } \\
\text { days }\end{array}$ & $\begin{array}{c}\text { Cours } \\
\text { e } \\
\text { (No.) }\end{array}$ & $\begin{array}{c}\text { Partici- } \\
\text { pants } \\
\text { (No.) }\end{array}$ & $\begin{array}{c}\text { Man } \\
\text { days }\end{array}$ \\
\hline A. & $\begin{array}{l}\text { International Training/ } \\
\text { Workshop/ Seminar/ } \\
\text { Conference/ Orientation } \\
\text { Programme }\end{array}$ & 04 & 31 & 267 & 05 & 41 & 335 \\
\hline B. & $\begin{array}{l}\text { National Training Course/ } \\
\text { Professional Training Course }\end{array}$ & 71 & 3388 & 34120 & 79 & 4100 & 33120 \\
\hline & Total & 75 & 3419 & 34387 & 84 & 4141 & 33455 \\
\hline
\end{tabular}

Source: Ashan et al., 2015 
Table 4: Achievement of Courses, Participants and Man days against Target in the Year 2014-15

\begin{tabular}{|c|l|c|c|c|c|c|c|}
\hline S1. & \multicolumn{1}{|c|}{ Nature of Course } & \multicolumn{3}{c|}{ Target } & \multicolumn{3}{c|}{ Achievement } \\
\cline { 3 - 8 } No. & $\begin{array}{c}\text { Course } \\
\text { (No.) }\end{array}$ & $\begin{array}{c}\text { Partici- } \\
\text { pants } \\
\text { (No.) }\end{array}$ & $\begin{array}{c}\text { Man } \\
\text { days }\end{array}$ & $\begin{array}{c}\text { Course } \\
\text { (No.) }\end{array}$ & $\begin{array}{c}\text { Partici- } \\
\text { pants } \\
\text { (No.) }\end{array}$ & $\begin{array}{c}\text { Man } \\
\text { days }\end{array}$ \\
\hline A. & $\begin{array}{l}\text { International Training/ Workshop/ } \\
\text { Seminar/ Conference/ Orientation } \\
\text { Programme }\end{array}$ & 03 & 45 & 340 & 02 & 31 & 396 \\
\hline B. & $\begin{array}{l}\text { National Training Course/ } \\
\text { Professional Training Course }\end{array}$ & 81 & 3905 & 39375 & 86 & 3620 & 39174 \\
\hline \multicolumn{2}{|}{ Total } & 84 & 3950 & 39715 & 87 & 3651 & 39570 \\
\hline
\end{tabular}

Source: Ashan et al., 2015

The percentage of the attainment in performance of training was about $83 \%$ of the objective (Ahsan et al., 2013). In 2013-2014, 84 courses were organized compared to the target of 75 . There were 4141 versus the target of 3419 (Table-3). The attainment in the performance of the training events of the academy was $94.78 \%$ of the target in this year, greater than that of the earlier year (Ahsan et al., 2015).

Table 4 shows that the performance of the training events of the academy was greater (99.63\%) in 2014-2015 than in the preceding year. 87 courses with a total of 3651 participants were conducted. It can be seen that the percentages of attainment of courses and attainment of presence of participants were more than hundred percent in 2013-2014 and in 2014-15. It was 106 percent and 114 percent correspondingly in 2013-14 and $104.70 \%$ and $92.43 \%$ correspondingly during $2014-15$.

\section{Opinion Regarding Training Functions of BARD}

Figure 1 presents that $15(75 \%)$ found the performance in the BARD trainings as very good. The reasons behind this were that the outcomes of research and action research were made use of in training; that the annually number of training was good; that differentiated training has been delivered; that international training has been delivered as well; that the annual targets were achieved; that backing to the government and nongovernment societies was delivered; that attractive allowances were delivered to the trainers; that excellence was confirmed; and that trainings were centered on the needs of the participants. $25 \%$ of the respondents expressed that the training performance was good. There were no answers on average, little and not satisfactory choice. Therefore, it can be assumed that, the performance of the training task of BARD was very good. 
Figure 1. Performance of Training Functions of the Academy

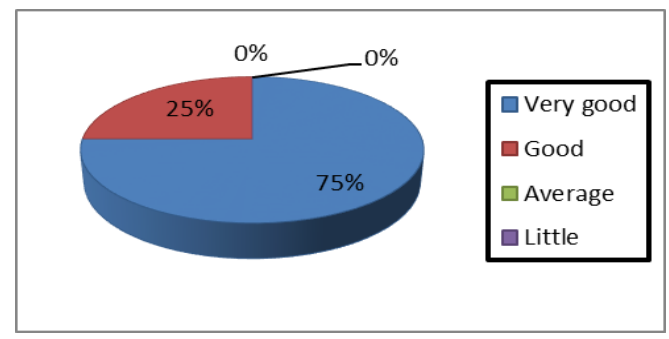

Source: author's field survey, 2016

\section{Research}

The Academy has been conducting socio-economic research since its initiation. The findings of the research are utilized as training resources and efforts for beginning action research by the academy itself, and as info ingredients and policy ideas by the Planning Commission, Ministries and Policy Makers for developping programmes. In some specific circumstances, these are well circulated amongst the international organizations and societies (Rahman et. al, 2013). Throughout the last 54 years, Harvard University, Michigan State University, Bath University, Upsala University, Gottingen University, Kyoto University, APDC, UNDP, FAO, UNESCO, JICA, CIRDAP, IDRC and Population Council have become the key international research agents of BARD. The academy is very diligently connected to the Center for Integrated Rural Development for Asia and the Pacific (CIRDAP), as well as to the National IRD Centre in Bangladesh. Moreover, it is functioning for SAARC as the National Liaison Center in the arena of rural development.

Table 5: Summary of Progress of Research Activities during the Year 2012-13

\begin{tabular}{|l|l|c|}
\hline \multicolumn{2}{|l|}{ Carried Over Research Studies of Previous Year } \\
\hline 1. & Under Course of Publication & 02 \\
\hline 2. & Ultimate Report Completed & 02 \\
\hline 3. & Draft Report Writing Phase & 03 \\
\hline 4. & Improvement Phase as per RD Commentaries & 01 \\
\hline 5. & Report Sent to CIRDAP & 01 \\
\hline 6. & Report Sent to Sponsoring Organization & 01 \\
\hline 7 & Others Total & 12 \\
\hline \multicolumn{2}{|c|}{} \\
\hline b. Research Studies During the Year 2012-13 & 03 \\
\hline 1. & Ultimate Report Submitted & -- \\
\hline 2. & Final Report Writing Phase & 01 \\
\hline 3. & Draft Report Writing Phase & 01 \\
\hline 4. & Data Collection Finished & 07 \\
\hline 5. & Data Collection Phase & 12 \\
\hline \multicolumn{2}{|c|}{ Total } & 24 \\
\hline
\end{tabular}

Source: Zabid et al., 2013 
The faculty members of BARD have an extensive series of knowledge in the arena of research, training and action research. Moreover, each year BARD conducts researches supported by GOs, NGOs and global organizations. The academy greets desires to conduct research from any organization, domestic or globally. Demands for conducting researches are prepared to the Director General, BARD or Director (Research), BARD. Publications of research are accessible on the publication unit of BARD. Nearly all respondents had an appreciable method about the research effort. They stated that, even some donor supported researches are conducted currently through this academy and this is the best indication of academic standing. Only $25 \%$ of the respondents stated that there was a general difficulty in sample size and occasionally probable result cannot be fulfilled for the stress of the desk bound task. The summary of the research activities between 2013 and 2015 is shown in Table 6.

Table 6: Summary of the Progress of Research Studies during the Year 2013-14 and 2014-15

\begin{tabular}{|l|l|c|}
\hline \multicolumn{1}{|c|}{ S1. No. } & \multicolumn{1}{|c|}{ Current Status } & Number of Researches \\
\hline 1. & Proposal Writing Stage & 02 \\
\hline 2. & Questionnaire Finalized & 02 \\
\hline 3. & Data Collection & 01 \\
\hline 4. & Tabulation Stage & 01 \\
\hline 5. & Draft Report Writing Stage & 04 \\
\hline 6. & Submitted to Research Division & 01 \\
\hline 7. & Draft Report Sent to External Reviewers & 01 \\
\hline 8. & Sent to Researcher for Improvement & 02 \\
\hline 9. & Report Improvement Stage & 02 \\
\hline 10. & Report Submitted to Sponsoring Agencies & 03 \\
\hline 11. & Process of Printing & 02 \\
\hline 12. & Report Published & 03 \\
\hline \multicolumn{2}{c}{ Total } & 24 \\
\hline
\end{tabular}

Source: Zahid et al., 2015

\section{Opinion Regarding Research Functions of BARD}

Figure 2 shows that five respondents found the performance of research tasks of BARD to be very good. The reasons behind their view were that affording to the mandate, the annual number of researches was satisfied; varied researches were completed here; researches were published in journal articles and books; although there were high amounts of work, research activities were going forward and attainments were good. Twelve respondent stated that the performance of research tasks of BARD was as good. The logics behind this were that each year 7 to 10 researches were finished; due to the high amount of work, the speed of research slowed down; sample size was insignificant - without large sample size actual condition could not discover; each year a good quantity of researches were printed; in recent time, donor funded researches have amplified; work was done multi-facet side; quality was not confirmed adequately; government policy persuading research was required. Three respondents expressed that the performance of research of BARD was on average. The logics 
behind this were that the researches were not sufficiently pacific and that there was a time restriction to accomplish the research. Nobody saw the performance in research as not satisfactory. Therefore, it can be thought that, the performance of the research activities of BARD was good.

Figure 2. Performance Regarding Research Functions of $B A R D$

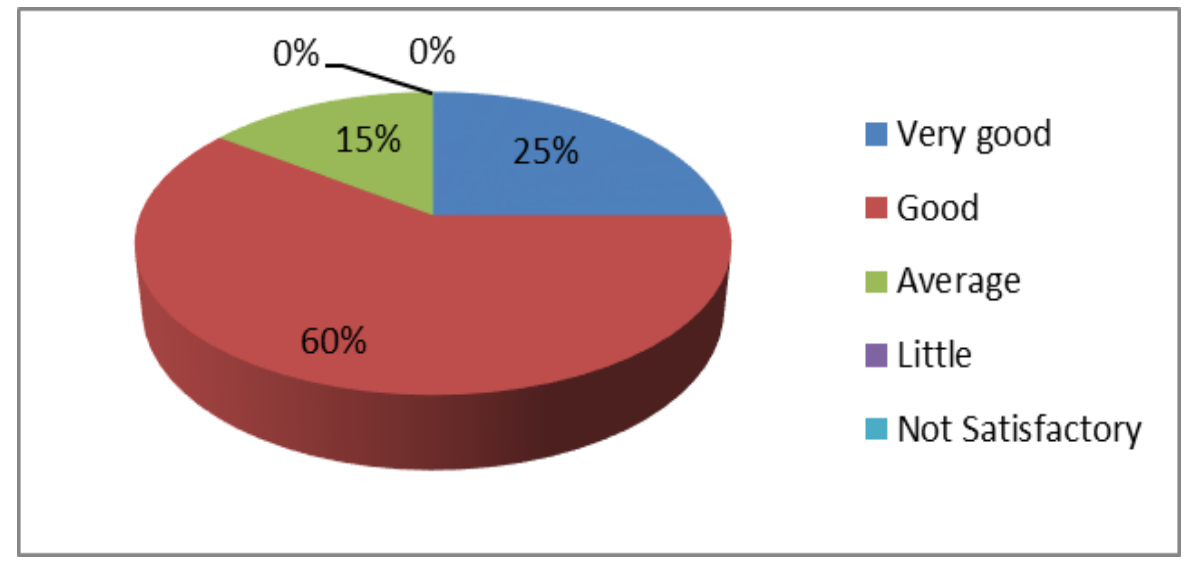

Source: author's field survey, 2016

\section{Action Research}

BARD conducts experimental research to advance replicas of upgraded institutes, organizational arrangements, management and approaches of production. The action research events generally include the village dwellers, development organizations, government officials and local councils. Up to now, the Academy has directed more than 50 experimental projects on numerous facets of rural development. BARD has been capable to develop the following rural development models that have previously been replicated all over the state as mechanisms of the Comilla Model through pilot investigations:

a) Two-tier Cooperatives;

b) Thana (Currently Upazila) Training and Development Centre (TTDC);

c) Rural Works Programme (RWP);

d) Thana (Currently Upazila) Irrigation Programme (TIP).

Moreover, the government has been reproducing two current representations of BARD: the Comprehensive Village Development Programme (CVDP) and the Small Farmer and Landless Development Project (Islam et. al., 2015). Table 7 indicates nine continuing action researches of BARD throughout the period 2012-13. Key Four projects were externally supported and two s were under Non-ADP budget. 
Table 7: Action Research Projects of BARD (2012-13)

\begin{tabular}{|l|l|c|}
\hline S1. No. & \multicolumn{1}{|c|}{ Category of Projects } & Number \\
\hline 1. & Annual Development Programme (ADP) & 1 \\
\hline 2. & Project Under Non-ADP Budget (PPNB) & 2 \\
\hline 3. & External Supported Project (ESP) & 2 \\
\hline 4. & BARD Revenue Project (BRP) & 9 \\
\hline \multicolumn{2}{|c|}{ Total } \\
\hline
\end{tabular}

Source: Ullab et. al., 2013

The Academy executed five projects throughout 2013-14 and 2014-15, as revealed in Table 8.

Table 8: Action Research Projects of BARD during 2013-14 and 2014-15

\begin{tabular}{|c|l|c|}
\hline S1. No. & \multicolumn{1}{|c|}{ Category of Projects } & Number \\
\hline 1. & Annual Development Programme (ADP) & 1 \\
\hline 2. & External Supported Project (ESP) & 2 \\
\hline 3. & BARD Revenue Project (BRP) & 2 \\
\hline \multicolumn{2}{|c|}{ Total } & 5 \\
\hline
\end{tabular}

Source: Sharifullah, et. al., 2015

\section{Opinion Regarding Action Research Functions of BARD}

Figure 3 shows that two respondents found the action research of BARD to be very good. The reasons behind as stated by the respondents were that the action researches of BARD were the backbone of the institution. Two respondents stated that the performance of action research tasks of BARD was good. The reason behind this was that BARD was doing action research, but it is subject to government process and government provision of fund in action research which goes through an extended and timely process, identified as problematic. Twelve respondents $(60 \%)$ stated the performance of action research tasks of BARD as average. The causes behind their view were that the government did not deliver finance to BARD; no prominence was provided for the proposal of projects submitted by BARD. Five respondents $(25 \%)$ expressed that performance of action research tasks of BARD was poor (little). The reasons behind this were that throughout the last seven or eight years, BARD had not gotten government reserves in new assignments; there was difficulty throughout the project approval process of government; no wide-ranging project was available and poor connection with the donor funding organization. 
Figure 3. Performance Regarding Action Research

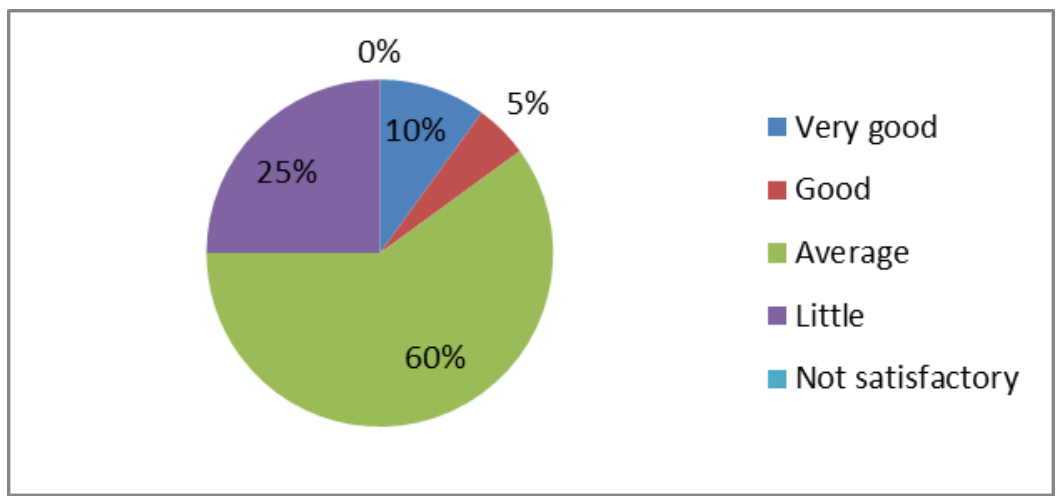

Source: author's field survey, 2016

\section{Challenges of BARD According to its Activities in the Age of Globalization}

A Yes/No question was asked whether the contemporary performance of BARD is compatible in the globalized world. Figure 4 shows that $15(75 \%)$ respondents stated "no" and that $5(25 \%)$ stated "yes". Therefore, it can be assumed that BARD should make more efforts to improve compatibility in the globalized world.

Figure 4. Opinion Regarding Compatibility in the Globalized World

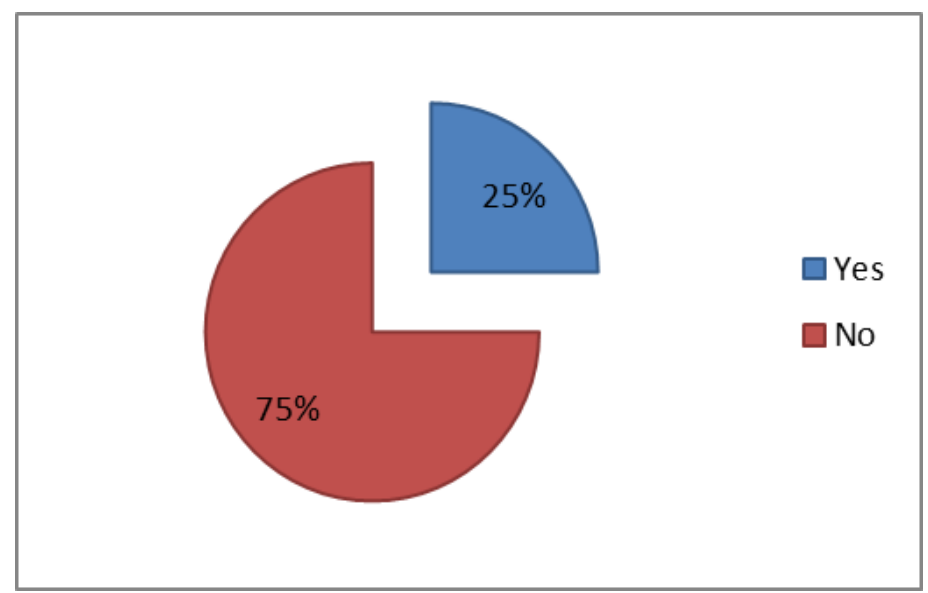

Source: author's field survey, 2016 
Several reasons were also provided on why BARD was perceived as incompatible in the globalized world, as depicted in Table 9.

Table 9: Opinions regarding the Incompatibility of BARD in the Globalized World

\begin{tabular}{|l|l|c|c|}
\hline $\begin{array}{c}\text { Sl. } \\
\text { No. }\end{array}$ & \multicolumn{1}{|c|}{ Opinion } & $\begin{array}{c}\text { Number of } \\
\text { Respondents }\end{array}$ & $\begin{array}{c}\text { Percentage } \\
\mathbf{( \% )}\end{array}$ \\
\hline 1. & Insufficient expert faculty & 6 & $30 \%$ \\
\hline 2. & Lack of suitable people in suitable field & 1 & $5 \%$ \\
\hline 3. & Poor technological provision & 3 & $15 \%$ \\
\hline 4. & Poor international connection & 8 & $40 \%$ \\
\hline 5. & Lack of vision & 2 & $10 \%$ \\
\hline 6. & Deficiency of professionalism of the faculty & 1 & $5 \%$ \\
\hline 7. & Lack of spontaneousness & 1 & $5 \%$ \\
\hline 8. & Lack of international knowledge & 1 & $5 \%$ \\
\hline
\end{tabular}

Source: Author's field survey, 2016 (N.B.: multiple answers recorded)

Table 9 discloses that there are numerous causes behind the incompatibility of BARD in the globalized world. Eight respondents mentioned the poor international, while six the lack of sufficient of expertise of the faculty. Poor technological provision has been cited by three respondents, while two have named the lack of vision. The other matters got single answers.

Rural development can be provocative in a globalized world. Yet, we still have a solid belief in Dr. Akhter Hameed Khan's viewpoint, principally his importance on the cooperative power and understanding. To cope with this kind of intricate social dynamics, involvement is the best method to continue. Keeping this in mind, BARD retains up its practice of participatory improvement and upholds frankness on work that helps to develop good relationships with a wide range of clients as well. It has been discovering challenges along with opening up new opportunities for promotion of rural products and how associations could be a key player in this respect. Permitting to the opinion articulated by the respondents, some key challenges about this study are given next:

\section{For the Research Function Perspective}

a) There are some difficulties of area / field choice (small sample size or narrow extents).

b) Timing difficulty for lots of desk-bound work and other internal events.

c) Very few rooms for comparative studies with other link organizations.

d) Research yields are not highlighted in the policy making layer.

e) There is no proficiency in contemporary technology centered research.

f) Allowance for the researcher is not adequate enough to make a good effort.

g) Inadequate quantitative analysis. 


\section{For the Action Research Function Perspective}

a) Lack of skills for project approval procedure.

b) Deficiency of time management for funding procedure from the government.

c) Be contingent on government's choice and approach.

d) Insufficient manpower.

e) Nonappearance of harmonization between pertinent ministry and academy.

\section{For the Training Related Challenges Function Perspective}

a) Deficiency of Training Need Assessment (TNA) procedure.

b) Lack of e-learning procedure.

c) Insufficient ICT associated apparatus and backdated arrangement.

d) Insufficient manpower.

e) Need some capability building projects for self-improvement.

\section{Looking Forward for Better Performance}

The study showed that BARD attained its objectives in training courses. However, excessive quantities of training courses and numbers of trainees may decline the quality of training. It is essential to confirm quality. There is a need for more proficiency and a need for a more capable trainer as well. E-learning skills and ICT technology are needed for enhanced training. In terms of research, it is important to increase the allowances so as to better motivate the researchers. The extent of research is essential to be comprehensive to get superior findings. Prominence needs to be given to contemporary technology-centered research. In the matter of the action research, finance is most important, accompanied by a necessity of knowledge of the project approval procedure, ample manpower and appropriate harmonization between the pertinent ministries and the Academy.

\section{Conclusions}

Dynamic forces of rural development in Bangladesh have transformed vastly in a globalized world. At present, globalization is usually acknowledged as an appealing force distressing many facets of human life. Unhindered trade, extraordinary progress of Information and Communications Technologies (ICTs) and a combination of sociocultural aspects through the world seem to be key concerns of globalization. So as to combat the condition, the pressures have to be apportioned and prospects grabbed. The forceful progression of globalization together with the market economy has been insistently shifting the ancient ideas, performs and arrangements of rural development, particularly in the developing states (Rahman, 2014). BARD is globally admired for its 
many groundbreaking mechanisms in the arena of rural development in Bangladesh. The Comilla model of Rural Development, a set of reciprocally helpful models of development, formed durable influences on altering the survival and living situation of the rural underprivileged people. As the majority of Bangladeshi live in rural areas, it is vital to create a possibility to work with so many people. The swiftly shifting worldwide inclusive development situation has introduced a new philosophy about rural development events, importance and planning procedures. Through this strategic blueprint, a strong will is extremely essential to support BARD and deal with the shifting conditions in the globalized world.

\section{References}

Aguinis, H. (2011). Performance Management. New Delhi: Dorling Kindersley India Pvt. Ltd.

Ahmed, S., \& Quddus M. A. (1993). A Framework for Future Activities of BARD: Background Work Plan \& Strategies for Implementation. Comilla: BARD.

Ahsan, K., Quader, M. A., Paul, J. R., \& Islam, M. N. (2013). Annual Report on Training: 2012-13. In: M. M. Rahman, M. A. H. Bhuyan, \& A. Mahmuda (Eds.), Annual Report 2012-2013 (pp.3-32). Comilla: BARD.

Ahsan, K., Munshi, S. K., Sultana, F. N. \& Nahar, S. (2015). Annaul Report on Research 2013-14 \& 2014-15. In: M. S. Islam, M. A. Taleb, \& F. Yeasmin, (Eds.) Annual Report 2014-2015 (pp. 4-58). Comilla: BARD.

Ahsan, K., Rahman, M. M. \& Rahim, J. (2012). Annual Report on Research. In: Chowdhury, M. H., Munshi, S. K. and Khan, A. (eds.). Annual Report 2010-2011. Comilla: BARD.

Aminuzzaman, S. M. (2011). Essentials of Social Research. Dhaka: Osder Publications.

Armstrong, M. (2006). Performance Management Key Strategies and Practical Guidelines. London: Kogan Page.

BARD (1973). Bangladesh Academy for Rural Development, Kotbari, Comilla: A Brief Review. Comilla: BARD.

BARD (1986). Silver Jubilee 1959-1985. Comilla: BARD.

BARD (1991). Bangladesh Academy for Rural Development: An Introduction. Comilla: BARD.

BARD (n. d.). Facilities at BARD. Comilla: BARD.

Bhattacharjee, M. K. (2009). Dr. Akbter Hameed Khan: A Master of Making the Past Work for the Present. In: BARD (ed.): Shuborno Joyonti Swarok Grontha. Comilla: BARD.

Garcia, R. C. (2017). Profitability and efficiency evaluation of the financial management of a socio-economic intervention. Management \& Marketing. Challenges for the Knowledge Society, 12(2), 316-333.

Hasan, M. K. (2000). Globalisation and Its Implications for Rural Development. In: Barua, B. K. (ed.): Current Thoughts on Rural Development. Comilla: BARD.

Hossain, M. (2004). Poverty alleviation through agriculture and rural development in Bangladesh. CPD Occasional Paper Series, 39.

Hussain, S. M. A. (2011). Challenges of Globalization: How Bangladesh Can Adapt Itself to Reap the Best Benefits in the 21st Century. MIST Journal: GALAXY (DHAKA), 3.

Ignat, R., Stoian, M., \& Roşca, V. (2014). Socio-economic Aspects of rural Romania. Procedia Economics and Finance, 15, 1331-1338.

Islam, M. S., Taleb, M. A., \& Yeasmin, F. (eds.) (2015). Annual Plan (2015-16). Comilla: BARD. 
Islam, M. S., Taleb, M. A., \& Yeasmin, F. (eds.). (2015). Annual Report 2014-2015. Comilla: BARD.

Jalil, D. (2011). Globalization and its impact on Bangladesh economy. State University of Bangladesh.

Jora, O. D. (2006). Might the Globalization Button Turn the European Social Bohemia off?. Romanian Economic Journal, 9(21), 95-100.

Kabir, M. K., Quader, M. A., \& Guha, R. K. (eds.) (2004). Annual Report (2002-2003). Comilla: BARD.

Kibria, G. 2015. Sustainable energy for Rural Development in Bangladesh- Economic, Social and Environmental Benefits of Renewable energy. Sydneybashi-Bangla, Australia; Science \& Technology, Article 37.

Jashimuddin, M., Bhattacharjee, M. K., \& Rahman, M. M. (2005). Annual Plan (2004-2005). Comilla: BARD.

Lim, G. C. (2005). Globalization, spatial allocation of resources and spatial impacts: A conceptual framework. In: Globalization and Urban Development (pp. 13-27). Berlin/Heidelberg: Springer.

Meraj, M. (2013). Impact of globalization and trade openness on economic growth in Bangladesh. Ritsumeikan Journal of Asia Pacific Studies (RJAPS), 32, 40-50.

Pop, N. A., Drăghescu, F., \& Roşca, V. (2013). Global competition and Romania's national competitive advantage. The Annals of the University of Oradea. Economic Sciences, Tom XXII, 1807-1814. ISSN 1582-5450.

Rahman, M. M., Bhuyan, M. A. H., \& Mahmuda, A. (eds.) (2013). Annual Report 2012-2013. Comilla: BARD.

Rahman, M. M. (2014). Threats and Opportunities of Globalization for Rural Development: Bangladesh Perspectives. Thai Journal of Public Administration, 12(1), 31-31.

Sharifullah, A. K., Guha, R. K., Khan, A. and Mahmud, R. (2015). Annual Report on Action Research. In: M. S. Islam, M. A. Taleb, \& F. Yeasmin (Eds.): Annual Report 2014-2015. Comilla: BARD.

Ullah, A. K. S., Islam, M. S. and Mahmuda, A. (2013). Annual Report on Action Research: 2012-13. In: M. M. Rahman, M. A. H. Bhuyan, \& A. Mahmuda (Eds.): Annual Report 2012-2013. Comilla: BARD.

von Braun, J., \& Mengistu, T. (2009). Poverty and the Globalization of the Food and Agriculture System. In: J. Von Braun, R. E. Hill, \& R. Pandya-Lorch (Eds.): The Poorest and Hungry: Assessments, Analyses, and Actions. International Food Policy Research Institute (pp. 171-178).

Zahid, S. J. A., Rahman, M. M. \& Rahim, J. (2015). Annual Report on Research 2013-14 \& 2014-15. In: M. S. Islam, M. A. Taleb, \& F. Yeasmin (Eds.): Annual Report 2014-2015 (pp. 59-83). Comilla: BARD 